\title{
Research Article \\ Effects of Climate Change and Various Grassland Management Practices on Grasshopper (Orthoptera) Assemblages
}

\author{
Zoltán Kenyeres ${ }^{1}$ and Judit Cservenka ${ }^{2}$ \\ ${ }^{1}$ Acrida Conservational Research L.P., Deák Ferenc Street 7, Tapolca 8300, Hungary \\ ${ }^{2}$ Balaton Uplands National Park Directorate, Kossuth Street 16, Csopak 8229, Hungary \\ Correspondence should be addressed to Zoltán Kenyeres; kenyeres.zol@gmail.com
}

Received 7 April 2014; Revised 4 June 2014; Accepted 16 June 2014; Published 2 July 2014

Academic Editor: Tomasz S. Osiejuk

Copyright (c) 2014 Z. Kenyeres and J. Cservenka. This is an open access article distributed under the Creative Commons Attribution License, which permits unrestricted use, distribution, and reproduction in any medium, provided the original work is properly cited.

\begin{abstract}
Influence of different grassland management practices on Orthoptera assemblages inhabiting humid grassland areas was studied since 2003 to 2011. The examined sites were within the protected area of Balaton Uplands National Park. The physiognomy and climatic conditions of the studied habitats were similar but their land use types were significantly different. After the preliminary analyses of Nonmetric multidimensional scaling, neighbour joining clustering, and Spearman rank correlation, we examined the possible effects of such independent variables as land use (nonmanagement, mowing, grazing), microclimate (humidity and temperature), regional macroclimate (annual and monthly mean temperatures and rainfall), using General Linear Mixed Models, and canonical correlation analysis. Our results showed that the effect of grassland management practices on the organization of Orthoptera assemblages was at least as important as that of macro- and microclimate. Furthermore, grassland management could intensify the influence of several local and regional parameters. These results can help finding the most suitable type of grassland management to conserve the grasshopper assemblages.
\end{abstract}

\section{Introduction}

Revision of grassland management practices, based on aspects of invertebrate zoology, has become a hot issue due to global warming. Global [1] and local stress factors [2] combined may significantly intensify the effect of each other on assemblages of diverse [3], sensitive, and fast responding [4] insects. This cumulative negative pressure not only could reduce the biodiversity of local fauna but also change the distribution area of several species as well $[5,6]$.

The landscape structure in the Balaton Uplands Region (Hungary), being rich in natural habitats, is especially suitable to examine the interaction of grassland management and climate based parameters. The relatively large size, natural state [7], and rich structural connectivity [8] of habitats in the study area produced diverse and complex insect assemblages. This richness was also facilitated by a variety of long-used traditional habitat management practices [9].

Under the pressure of climate change, the most successful type of grassland management [10-12] can be determined best through selecting the orthopterans [13] as indicator group, like butterflies [14] and ground-dwelling spiders [15]. Additionally, orthopterans include a relatively limited number of species that can be easily handled [16], allow for objective sampling methods, and are quick and clear habitat indicators [17-22].

The good applicability of orthopterans for monitoring grassland management is based on their strict dependency on horizontal and vertical vegetation structure [23] and on grassland microclimate [24] at species and assemblage levels. These features manifest themselves not only in the local abundance of species but in the range of species groups with similar ecological requirements [25]. The strong vegetation and microclimate dependency come from several factors, including energetic connections with the habitats $[26,27]$, specific thermal requirements [28], differences in postdiapause egg development (PDD) of thermophilic, mesophilic and hygrophilic species [29], and soil preferences of species that lay their egg in the soil [30]. Xerophilic species are characterized by long PDD, whereas hygrophilic and mesophilic ones have a short PDD [31], therefore composition and density of species that lay their eggs in the soil are controlled 
by climate change and grassland management factors, as key influences on PDD [29, 32, 33]. Based on these ecological facts, orthopterans are good, but as yet rarely researched focal taxon of grassland management $[24,34,35]$ and climate change [36-38].

Our study objective was to test the influence of different grassland management types on Orthoptera assemblages of humid grasslands and to examine the effects and interactions of local (grass height, temperature, and humidity) and regional (annual and monthly rainfall and annual and monthly mean temperatures) habitat parameters on them. Based on the above, we also aimed at finding the best type of grassland management to conserve the valuable grasshopper assemblages in the area.

\section{Study Areas}

The studied sites belong to the protected grounds of the Balaton Uplands National Park (Western Hungary): NySCf = Nyirád/Sár-álló/Calcareous fen, KSCf = Köveskál/Sásdirétek/Calcareous fen, LLCf = Lesencetomaj/Lesencei-láprét/ Calcareous fen, NySM = Nyirád/Sár-álló/Molinietum and LKM = Lesencetomaj/Körtvélyes/Molinietum (Figure 1).

The wider biogeographical microregions of the study area (Balaton Region, Balaton Uplands, Western Bakonyalja) have a moderately warm/moderately dry climate with an annual mean temperature of 9.5-10.0 Celsius; average maximum and minimum temperatures of $\sim$ plus 32.0-33.0 Celsius and $\sim$ minus 13.0-14.0 Celsius; an annual rainfall of approximately $700 \mathrm{~mm}$ (380-440 $\mathrm{mm}$ in the vegetation period); an average snow-cover of 35-44 days; and an aridity index ranging from 1.00 to 1.08 [39].

The examined fields are either basin areas, situated at low altitudes of 120-130 meters and surrounded by small (300-400 m) hills (KSCf, LLCf, LKM) or they are situated at the edge of hilly areas at an altitude of 190 metres (NySCf, NySM). All areas had formerly been covered by dense humid marshland vegetation until the 20th century when several parts of them were drained or cultivated. Still, the share of natural grassland and within that humid grassland in a 1,000 meter radius of the sampling sites remained relatively high (KSCf: $72 \%$ grasslands, $24 \%$ humid grasslands; LLCf: $57 \%$ grasslands, $11 \%$ humid grasslands; LKM: $47 \%$ grasslands, $6 \%$ humid grasslands, NySCf and NySM: 47\% grasslands, 6\% humid grasslands).

Although the physiognomy and climatic conditions of the sampled habitats were similar, their land use types were significantly different: two areas, the calcareous fen of NySCf and the Molinietum of LKM were not managed at all during the study period (2003-2011); the calcareous fen of KSCf consisted of unmanaged areas and areas managed in different ways (yearly mowing and moderate grazing); LLCf was not managed either; however, a two-yearly mowing of Cladium mariscus was applied to help the growth of other grass species; and NySM was mowed once a year.

The land use history of the areas was also different. The calcareous fen and Molinietum of Nyirád (NySCf and NySM) were covered originally too by grasslands but their

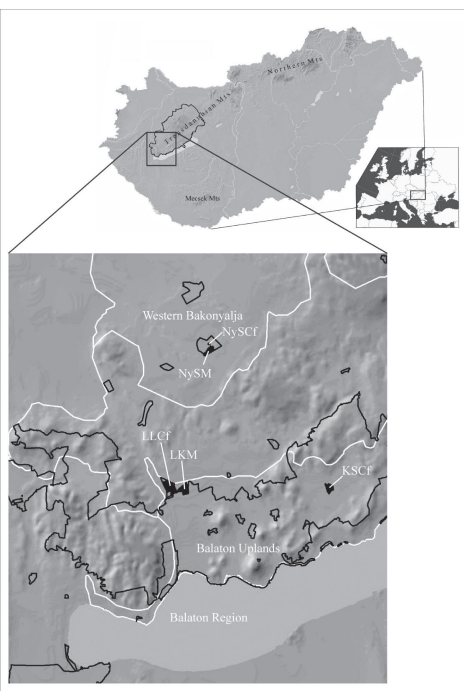

FIGURE 1: Map of the study area [black lines: borders of the protected grounds, white lines: borders of the biogeographical microregions, black patches: studied areas $(\mathrm{NySCf}=$ Nyirád/Sár-álló/Calcareous fen, KSCf = Köveskál/Sásdi-rétek/Calcareous fen, LLCf = Lesencetomaj/Lesencei-láprét/Calcareous fen, NySM = Nyirád/Sár-álló/Molinietum and LKM = Lesencetomaj/Körtvélyes/Molinietum)].

ground water level was artificially changed twice in the past: (1) bauxite-mining from the 1960s drained ground water by pumping and a large channel; (2) ten years ago, original water levels were restored by habitat reconstruction. The original grasslands of NySCf and NySM were not managed or mowed unsystematically. The Calcareous fen of Köveskál/Sásdi-rétek (KSCf) is also an original grassland that had been traditionally mowed and grazed extensively. During the last decades, the area was still mowed until the recent years when there was a switch to a practice of late summer grazing once a year. The calcareous fen of Lesencetomaj/Lesencei-láprét (LLCf) is also an original grassland. Its ground water level was also affected by the mining operations and draining but in the last decades the water supply has mainly been determined by the actual rainfall. Formerly, this grassland too was cattle grazed but in the last decades it was not managed or mowed only rarely within the nature management schemes of the National Park. The Molinietum of Lesencetomaj/Körtvélyes (LKM) is mainly covered by original grassland too. Its ground water level was again influenced by smaller drain channels; however, its water supply remained almost natural. Traditionally, the area was grazed moderately or mowed extensively but recently it has been left unmanaged as part of a larger overgrazed field.

For a detailed description of the sample areas and their environmental parameters see Tables $1(\mathrm{a})$ and $1(\mathrm{~b})$.

\section{Sampling Methods}

Detailed samplings were carried out within the HABITCHANGE project (European Regional Development Fund: 2CE168P3 in 2010 and 2011) (Figure 1). Two areas (KSCf 
TABLE 1: (a) The most important environmental parameters of the sampled areas; (b) main macroclimate parameters of the sampled areas.

(a)

\begin{tabular}{lccccccccccc}
\hline $\begin{array}{l}\text { Sampl. } \\
\text { area }\end{array}$ & $\begin{array}{c}\text { Height above } \\
\text { sea-level (m) }\end{array}$ & Bedrock & Exposure & Soil & $\begin{array}{c}\text { Local cover } \\
\text { of humid } \\
\text { grasslands }\end{array}$ & $\begin{array}{c}\text { Hab. size } \\
\text { (hect.) }\end{array}$ & $\begin{array}{c}\text { Veg. } \\
\text { cover }\end{array}$ & $\begin{array}{c}\text { Veg. av. } \\
\text { height }\end{array}$ & $\begin{array}{c}\text { Water } \\
\text { level (m) }\end{array}$ & $\begin{array}{c}\text { Landuse } \\
\text { (m) }\end{array}$ \\
\hline NySCf $^{*}$ & 190 & Gravel & - & fenny & $6 \%$ & 10 & $60-90 \%$ & $90-100 \mathrm{~cm}$ & $-0.8-0.0$ & Nonmanaged \\
KSCf $^{*}$ & 135 & Turf & - & fenny & $24 \%$ & 64 & $80-100 \%$ & $70-80 \mathrm{~cm}^{-1.5-0.1}$ & Mowing $^{2}$ grazing $^{3}$ \\
LLCf $^{*}$ & 120 & Turf & - & fenny & $11 \%$ & 84 & $70-90 \%$ & $80-90 \mathrm{~cm}$ & $-0.7-0.0$ & Mowing $^{4}$ \\
NySM $^{* *}$ & 195 & Gravel & - & sand & $6 \%$ & 50 & $80-90 \%$ & $40-60 \mathrm{~cm}$ & $-2.0-0.5$ & Mowing \\
LKM $^{* *}$ & 120 & Turf & - & turf & $6 \%$ & 30 & $70-90 \%$ & $60-80 \mathrm{~cm}$ & $-1.5-0.7$ & Nonmanaged \\
\hline
\end{tabular}

${ }^{1}$ before mowing and grazing; ${ }^{2}$ once a year (July, August); ${ }^{3}$ moderately $\left(0.1\right.$ beef/hectare) in late summer/autumn; ${ }^{4}$ mowing of Cladium mariscus had happened for two years in order to control its serious pressure on other grass species; ${ }^{*} \mathrm{Cf}=$ Calcareous fen, ${ }^{* *} \mathrm{M}=$ Molinietum.

(b)

\begin{tabular}{|c|c|c|c|c|c|c|c|c|c|c|c|c|}
\hline & \multicolumn{6}{|c|}{ Mean temperature $\left({ }^{\circ} \mathrm{C}\right)$} & \multicolumn{6}{|c|}{ Mean rainfall $(\mathrm{mm})$} \\
\hline & 2003 & 2005 & 2007 & 2009 & 2010 & 2011 & 2003 & 2005 & 2007 & 2009 & 2010 & 2011 \\
\hline April & 10.2 & 11 & 13.1 & 14 & 11.3 & 13.5 & 25 & 62 & 2 & 11 & 67 & 21 \\
\hline May & 18.1 & 16 & 17.4 & 16.3 & 16.2 & 16.2 & 22 & 60 & 93 & 70 & 132 & 19 \\
\hline June & 22.8 & 18.3 & 21.6 & 17.8 & 18.6 & 21 & 15 & 71 & 53 & 47 & 142 & 47 \\
\hline July & 22.1 & 20 & 21.9 & 21 & 21.8 & 21.2 & 72 & 120 & 53 & 84 & 37 & 86 \\
\hline August & 23.2 & 18 & 20 & 21.2 & 21 & 21.8 & 66 & 204 & 172 & 63 & 155 & 41 \\
\hline September & 15.8 & 16.1 & 14 & 17.6 & 14.5 & 17.5 & 32 & 59 & 122 & 31 & 132 & 23 \\
\hline Annual & 10.9 & 9.7 & 11 & 10.9 & 9.8 & 11.1 & 490 & 765 & 840 & 700 & 950 & 350 \\
\hline
\end{tabular}

and LLCf) were studied in the framework of the Hungarian Biodiversity Monitoring System too in 2003, 2005, 2007, and 2009 (Figure 1), providing current data that can be used for midterm analyses of grasshopper assemblages and habitat-variables. Three-five sampling sites per sampling areas (KSCf, LLCf, LKM, NySCf, NySM; see Figure 1) were studied annually in June, July, August, and September (a total of 17 sampling sites, 312 samplings). The average distance between the sampling areas was 10 kilometers and between the sample sites it was 50 metres. Selection of the sampling areas was based on habitat-structure, land use, macro- and microclimatic conditions, and landscape history. Thus, areas with high natural value, well representing the landscape structure of the microregion, and affected by different land use types were selected for the study. The samplings were carried out under very different weather conditions during the years, which was important due to the strong waterdependency of the studied habitats.

Grasshoppers were collected by sweep netting in $10 \times$ $10 \mathrm{~m}$ quadrates. Each sampling consisted of 300 sweeps (using sweep nets with a diameter of $30 \mathrm{~cm}$, samplings were carried out in each site in the same intervals of the days, from 10 to 12 and from 14 to 16 ; sweep net was examined after each 100 sweep). These sweep net samplings were complemented by direct collection, whose data was also incorporated into the results through simple addition. The observed larvae were also recorded but they were excluded from the analysis.

Local habitat parameters were recorded at 5 pseudorandom plots within the sampling quadrates. We measured the following variables: grass height $(\mathrm{cm})$, land use type, and temperature (Celsius) and humidity (\%) at surface level and at heights of $10,20,30$, and $120 \mathrm{~cm}$ (the latter two were measured with TESTO 615).

Regional climate data of the study period were obtained from the nearest measuring points of the Hungarian Weather Service (Keszthely and Sümeg at $\sim 20 / \sim 16 \mathrm{~km}$ from the sampling areas). We used the following macroclimatic parameters in our models: annual mean temperatures and rainfall and monthly mean temperatures and rainfall in April, May, June, July, August, and September.

Landscape structure and share of land use types in percentages in a radius of $1 \mathrm{~km}$ around the sampling areas were determined on the basis of aerial photographs and CORINE LC maps.

\section{Statistical Analysis}

Orthoptera samples collected at the same place at the same time were merged into combined samples (a total of 64 combined samples). Analyses were carried out using the relative frequency of these merged samples. Microclimatic and grass height data were determined the same way (averaging the measurements taken on different plots at the same time). In case of the microclimatic data, we calculated relative values (measurements at $120 \mathrm{~cm}$ were considered 0 ) for our analysis and models. Further examined parameters of the Orthoptera assemblages were species richness, number of thermophilic species, number of hygrophilic species, abundance of thermophilic species, abundance of hygrophilic species, number of pratinicole species, abundance of pratinicole species, number of graminicole species, abundance of graminicole species, and abundance and relative frequency of species with 
TABLE 2: Synthetic table of the collected material [life-forms: pra: pratinicole, arbu: arbusticole, psps: pseudopsammophilic, sil: silvicole, gra: graminicole, geo: geophilic; hab req: habitat requirements, hygr: hygrophilic, m-hygr: moderate-hygrophilic, ther: thermophilic, mes: mesophilic, m-ther: moderate-thermophilic].

\begin{tabular}{|c|c|c|c|c|c|c|c|c|}
\hline \multirow{2}{*}{ Species } & \multirow{2}{*}{ Abbr. } & \multirow{2}{*}{ Life-form } & \multirow{2}{*}{ Hab. req. } & \multicolumn{5}{|c|}{ Total specimens per habitat types } \\
\hline & & & & KSCf & LLCf & NySCf & LKM & NySM \\
\hline Conocephalus discolor (Thunberg, 1815) & Condis & pra & hygr & 136 & 174 & 143 & 46 & 44 \\
\hline Conocephalus dorsalis (Latreille, 1804) & Condor & pra & hygr & 7 & 7 & 0 & 0 & 0 \\
\hline Ruspolia nitidula (Scopoli, 1786) & Rusnit & pra & m-hygr & 9 & 0 & 0 & 0 & 0 \\
\hline Phaneroptera falcata (Poda, 1761) & Phafal & arbu & ther & 0 & 5 & 5 & 31 & 19 \\
\hline Leptophyes albovittata (Kollar, 1833) & Lepalb & arbu & ther & 0 & 1 & 0 & 1 & 3 \\
\hline Isophya costata (Brunner v. W., 1878) & Isocos & pra & mes & 2 & 0 & 0 & 0 & 0 \\
\hline Gampsocleis glabra (Herbst, 1786) & Gamgla & psps & ther & 0 & 0 & 0 & 2 & 0 \\
\hline Polysarcus denticauda (Charpentier, 1825) & Polden & pra & mes & 1 & 0 & 0 & 0 & 0 \\
\hline Tettigonia viridissima Linnaeus, 1758 & Tetvir & arbu & mes & 10 & 2 & 0 & 0 & 3 \\
\hline Decticus verrucivorus (Linnaeus, 1785) & Decver & pra & mes & 9 & 0 & 0 & 2 & 18 \\
\hline Pholidoptera fallax (Fischer, 1853) & Phofal & sil & ther & 7 & 0 & 0 & 0 & 0 \\
\hline Platycleis albopunctata (Goeze, 1778) & Plaalb & pra & ther & 2 & 0 & 0 & 0 & 0 \\
\hline Bicolorana bicolor (Philippi, 1830) & Bicbic & pra & $\mathrm{m}$-ther & 12 & 0 & 0 & 15 & 69 \\
\hline Roeseliana roeselii (Hagenbach, 1822) & Roeroe & pra & m-hygr & 99 & 14 & 4 & 20 & 36 \\
\hline Calliptamus italicus (Linnaeus, 1758) & Calita & gra & ther & 0 & 1 & 0 & 0 & 1 \\
\hline Pezotettix giornae (Rossi, 1794) & Pezgio & gra & ther & 0 & 2 & 0 & 0 & 0 \\
\hline Stethophyma grossum (Linnaeus, 1758) & Stegro & pra & hygr & 2 & 1 & 0 & 0 & 0 \\
\hline $\begin{array}{l}\text { Mecostethus parapleurus } \\
\text { (Hagenbach, 1822) }\end{array}$ & Mecpar & pra & hygr & 5 & 0 & 0 & 0 & 0 \\
\hline Chrysochraon dispar (Germar, 1834) & Chrdis & pra & m-hygr & 59 & 52 & 0 & 137 & 14 \\
\hline Euthystira brachyptera (Ocskay, 1826) & Eutbra & pra & mes & 117 & 81 & 7 & 249 & 93 \\
\hline Chorthippus biguttulus (Linnaeus, 1758) & Chobig & pra & m-ther & 6 & 0 & 0 & 2 & 10 \\
\hline Chorthippus brunneus (Thuinberg, 1815) & Chobru & pra & m-ther & 14 & 9 & 0 & 15 & 15 \\
\hline Chorthippus mollis (Charpentier, 1825) & Chomol & pra & mes & 15 & 6 & 0 & 30 & 7 \\
\hline Chorthippus dorsatus (Zetterstedt, 1821) & Chodor & pra & mes & 8 & 0 & 0 & 3 & 4 \\
\hline $\begin{array}{l}\text { Pseudochorthippus parallelus } \\
\text { (Zetterstedt, 1821) }\end{array}$ & Psepar & pra & mes & 164 & 34 & 15 & 95 & 63 \\
\hline $\begin{array}{l}\text { Pseudochorthippus montanus } \\
\text { (Charpentier, 1825) }\end{array}$ & Psemon & pra & mes & 102 & 14 & 18 & 9 & 7 \\
\hline Omocestus rufipes (Zetterstedt, 1821) & Omoruf & pra & mes & 0 & 0 & 0 & 0 & 1 \\
\hline Omocestus petraeus (Brisout, 1855) & Omopet & gra & ther & 1 & 0 & 0 & 0 & 0 \\
\hline Stenobothrus lineatus (Panzer, 1796) & Stelin & pra & m-ther & 14 & 10 & 0 & 1 & 6 \\
\hline Tetrix subulata (Linnaeus, 1758) & Tetsub & geo & hygr & 0 & 2 & 0 & 0 & 0 \\
\hline Tetrix tenuicornis (Sahlberg, 1891) & Tetten & pra & ther & 0 & 1 & 0 & 0 & 0 \\
\hline $\begin{array}{l}\text { Euchorthippus declivus } \\
\text { (Brisout de Barneville, 1848) }\end{array}$ & Eucdec & gra & ther & 0 & 0 & 0 & 7 & 0 \\
\hline Aiolopus thalassinus (Fabricius, 1781) & Aiotha & gra & $m$-ther & 12 & 1 & 0 & 0 & 0 \\
\hline
\end{tabular}

a relative share larger than 2 percent. Ecotype needs and lifeform classification of the grasshopper species were based on definitions by Ingrisch and Köhler [40].

The preliminary analysis of the collected data, using nonmetric multidimensional scaling (MDS) and neighbour joining clustering (PAST 1.95 software, [41]) showed significant differences between samples taken on different habitat types at different times. These differences cannot be explained purely by phenological factors. The Spearman rank correlation of background variables suggested that the effects of land use and related micro- and macroclimatic factors could often be imperative on the organization and actual abundance of Orthoptera species.

Based on the above preliminary examination, we analysed the possible effects of independent variables, that is, land management (mowing, grazing, and nonmanagement), 
TABLE 3: Results of testing effects of microclimate and management and their interactions on the species richness and abundance of the orthopteran species groups (general linear mixed model, one-way ANOVA, $n=64$ ).

\begin{tabular}{|c|c|c|c|c|c|c|c|}
\hline & \multicolumn{3}{|c|}{ Microclimate and management } & \multicolumn{4}{|c|}{ Macroclimate and management } \\
\hline & M & Mic & $\mathrm{Mic} \times \mathrm{M}$ & Ann & Ann $\times M$ & Seas & Ses $\times M$ \\
\hline \multicolumn{8}{|l|}{ Species richness } \\
\hline Thermophilic spp. & $3.24^{* *}$ & 0.56 & $17.81^{* *}$ & 1.44 & $4.51^{* *}$ & 1.01 & 1.62 \\
\hline Hygrophilic spp. & 1.51 & 0.78 & 2.56 & $2.52^{* *}$ & $2.67^{* *}$ & $2.02^{*}$ & 6.59 \\
\hline Pratinicole spp. & 0.87 & 2.20 & 2.67 & 0.42 & 0.51 & 0.43 & 0.51 \\
\hline Graminicole spp. & $2.53^{*}$ & 2.76 & $69.24^{* * *}$ & 1.44 & 1.48 & 1.44 & 1.48 \\
\hline \multicolumn{8}{|l|}{ Abundance } \\
\hline Thermophilic spp. & $3.21^{* *}$ & 2.37 & $5.04^{*}$ & 0.71 & 1.59 & 0.49 & 0.15 \\
\hline Hygrophilic spp. & $2.25^{*}$ & $4.35^{*}$ & 0.81 & 1.69 & $2.37^{*}$ & 1.35 & 2.39 \\
\hline Pratinicole spp. & $2.28^{*}$ & $44.97^{* * *}$ & 0.79 & $6.41^{* * *}$ & $10.11^{* * *}$ & $6.41^{* * *}$ & $10.10^{* * *}$ \\
\hline Graminicole spp. & $10.72^{* * *}$ & 0.53 & 3.04 & 1.25 & 0.72 & 1.25 & 0.72 \\
\hline
\end{tabular}

Model includes management (M), microclimate (Mic), annual and periodical (June, July, August, and September) macroclimate (Ann and Seas) and their interactions (Mic $\times \mathrm{M}$, Ann $\times \mathrm{M}$, Seas $\times \mathrm{M})$. Temperature $\left({ }^{\circ} \mathrm{C}\right)$ and humidity $(\%)$ on the ground surface and at heights of 10,20 , and $30 \mathrm{~cm}$ in the grassland were involved in Mic. Mean temperature and rainfall of the period were involved in Ann and Seas. $F$ values are given. ${ }^{*} P<0.05 ;{ }^{* *} P<0.005 ;{ }^{* * *} P<0.001$.

microclimatic factors (humidity and temperature), regional macroclimatic factors (annual and monthly mean temperatures and rainfall), and their interactions on Orthoptera assemblages and species, using General Linear Mixed Models. The provisional model, incorporating all possible effects of land management, microclimate, and macroclimate, was rejected because of the inevitable multicollinearity and indefinability of explanatory variables. Therefore, we tested the effects of land management and microclimate on macroclimate in separate models. A one-way analysis of variance (ANOVA) was performed using Statistica 6.0 (the random factor was not marked) [42].

To analyse the effects of local and regional climate on the structure of orthopterans, we conducted a canonical correlation analysis with logarithmically transformed data of annual, seasonal, and monthly (June, July, August, and September) rainfall; grass height determined by the actual land use type; and the relative frequencies of Orthoptera species occurring in minimum 5 samples.

\section{Results}

During the study we collected 2,506 Orthoptera specimens of 33 species. The most abundant species (Euthystira brachyptera (Ocskay, 1826), Conocephalus discolor Thunberg, 1815, Pseudochorthippus parallelus (Zetterstedt, 1821), Chrysochraon dispar (Germar, 1834), Roeseliana roeselii (Hagenbach, 1822), Bicolorana bicolor (Philippi, 1830), Phaneroptera falcata (Poda, 1761), Chorthippus mollis (Charpentier, 1825), and Chorthippus brunneus (Thunberg, 1815)) show great diversity in habitat requirements concerning vegetation structure and microclimate. Furthermore, the observed species greatly differ in tolerance to land use intensity and disturbances.

The linear mixed model of species richness and abundance of Orthoptera groups with different life-forms and habitat requirements showed a significant correlation between the abundance of graminicole/thermophilic species preferring short grass vegetation and the interaction of grassland management type and microclimate (Table 3). For the pratinicole species preferring tall grass vegetation, abundance was most significantly correlated with grassland microclimate but further correlations with interactions of macroclimate and grassland management type were also revealed. The abundance of graminicole species was strongly correlated with the interaction of microclimate and grassland management type.

In case of hygrophilic species, species richness was affected by not only microclimatic but macroclimatic parameters as well (Table 3). Furthermore, the ecotype-structure of the assemblages showed weaker correlations with local and regional factors than their life-form structure did.

For the dominant Orthoptera species, our linear mixed model showed strong significant correlation between abundance and interactions of grassland management type and microclimate (Table 4). These correlations could be observed in case of mesophilic species too (Euthystira brachyptera, Chrysochraon dispar, and Roeseliana roeselii) but they were more prominent for species with strict preference for tallgrass (Bicolorana bicolor) or short-grass vegetation (Chorthippus mollis, C. brunneus).

We found fewer and less significant correlations between macroclimate and species abundance. It seems that yearly macroclimate and grassland management type are more relevant than periodical microclimate (from June to September).

Examining the effects of macroclimate and grassland management type on humidity and temperature figures, it seemed that microclimate was mostly related to periodical macroclimate from June to September (Table 5). Average and specific (measured at surface level and at different heights) microclimatic values clearly correlated to periodical (June, July, August, and September) main temperatures and the average rainfall. Based on the significant correlations, the annual rainfall also affects the humidity of the grasslands. Our model indicated that the specific type of grassland management used, a determining factor of grass height, plays only a reduced role in determining grassland microclimate. 
TABLE 4: Results of testing effects of microclimate and management and their interactions on the dominant species of the studied orthopteran assemblages (general linear mixed model, one-way ANOVA, $n=64$, for abbreviations of the species see Table 2).

\begin{tabular}{|c|c|c|c|c|c|c|c|}
\hline & \multicolumn{3}{|c|}{ Microclimate and management } & \multicolumn{4}{|c|}{ Macroclimate and management } \\
\hline & $\mathrm{M}$ & Mic & $\mathrm{Mic} \times \mathrm{M}$ & Ann & Ann $\times M$ & Seas & Ses $\times M$ \\
\hline \multicolumn{8}{|l|}{ Abundance } \\
\hline Eutbra & $3.75^{* *}$ & $6.24^{*}$ & $6.46^{*}$ & 0.82 & 2.14 & $2.21^{*}$ & 1.46 \\
\hline Condis & 1.58 & 1.14 & 1.23 & 0.60 & 1.28 & 0.89 & 1.84 \\
\hline Chrdis & $2.15^{*}$ & 0.99 & 0.26 & 0.78 & $2.28^{*}$ & 0.61 & 0.79 \\
\hline Roeroe & 0.51 & $7.34^{*}$ & 1.37 & $2.27^{*}$ & 0.65 & $2.41^{*}$ & 0.49 \\
\hline Psepar & 0.69 & 2.14 & 0.99 & $2.15^{*}$ & 1.19 & 1.20 & 0.21 \\
\hline Bicbic & 0.91 & $5.33^{*}$ & $17.81^{* *}$ & 0.75 & 0.54 & 0.73 & 0.10 \\
\hline Chomol & $10.12^{* * *}$ & 0.36 & 1.26 & 1.50 & $4.50^{* *}$ & $2.05^{*}$ & 1.62 \\
\hline Chobru & $6.56^{* * *}$ & 0.53 & 2.56 & $2.02^{*}$ & 1.59 & 1.85 & 0.15 \\
\hline
\end{tabular}

Model includes management (M), microclimate (Mic), annual and periodical (June, July, August, and September) macroclimate (Ann and Seas) and their interactions (Mic $\times$ M, Ann $\times$ M, Seas $\times M$ ). Temperature $\left({ }^{\circ} \mathrm{C}\right)$ and humidity $(\%)$ on the ground surface and at heights of 10,20 , and $30 \mathrm{~cm}$ in the grassland were involved in Mic. Mean temperature and rainfall of the period were involved in Ann and Seas. $F$ values are given. ${ }^{*} P<0.05 ;{ }^{* *} P<0.005 ;{ }^{* * *} P<0.001$.

TABLE 5: Results of testing effects of macroclimate and management and their interactions on the microclimate of the studied grasslands (respective values of microclimate data were included $=$ the value measured at $120 \mathrm{~cm}$ was considered 0 ) (general linear mixed model, oneway ANOVA, $n=64)$.

\begin{tabular}{|c|c|c|c|c|}
\hline \multirow{2}{*}{ Microclimate } & \multicolumn{4}{|c|}{ Macroclimate and management } \\
\hline & Ann & Seas & M & $\mathrm{M} \times$ Seas \\
\hline \multicolumn{5}{|l|}{ Grassland humidity } \\
\hline Ground surface & $5.41^{* * *}$ & $5.22^{* * *}$ & $2.30^{*}$ & 1.62 \\
\hline $10 \mathrm{~cm}$ & $5.49^{* * *}$ & $7.42^{* * *}$ & $1.99^{*}$ & 1.33 \\
\hline $20 \mathrm{~cm}$ & $3.45^{* *}$ & $9.96^{* * *}$ & 1.47 & 1.52 \\
\hline $30 \mathrm{~cm}$ & $2.58^{*}$ & $11.12^{* * *}$ & 1.65 & 1.17 \\
\hline Average & $6.71^{* * *}$ & $8.46^{* * *}$ & $2.24^{*}$ & 1.29 \\
\hline \multicolumn{5}{|c|}{ Grassland temperature } \\
\hline Ground surface & $3.07^{*}$ & $8.62^{* * *}$ & $2.56^{*}$ & 1.29 \\
\hline $10 \mathrm{~cm}$ & 2.07 & $8.29^{* * *}$ & 1.37 & $2.15^{*}$ \\
\hline $20 \mathrm{~cm}$ & $3.59^{* *}$ & $8.00^{* * *}$ & 1.88 & $2.77^{* *}$ \\
\hline $30 \mathrm{~cm}$ & $2.93^{*}$ & $9.16^{* * *}$ & 1.69 & $5.15^{* * *}$ \\
\hline Average & $3.17^{*}$ & $9.23^{* * *}$ & $2.09^{*}$ & $2.43^{*}$ \\
\hline
\end{tabular}

Model includes annual macroclimate (Ann), periodical (June, July, August, and September) macroclimate (Seas, from June to July), management (M), and interactions of management and periodical (June, July, August, and September) macroclimate $(\mathrm{M} \times \mathrm{Seas})$. Mean temperature and rainfall of the period were involved in Ann and Seas. $F$ values are given. ${ }^{*} P<0.05 ;{ }^{* *} P<0.005 ;{ }^{* * *} P<0.001$.

The canonical correlation analysis based on annual, seasonal (spring), and monthly (June, July, August, and September) rainfall data and grassland management type as habitat variables showed (Figure 2) that the occurrence and abundance of mesophilic and especially hygrophilic species strongly correlated to annual and spring rainfall figures and taller vegetation (grass height). On Figure 2 it can be seen that species groups with different habitat requirements (hygrophilic and mesophilic versus thermophilic) are separated along the above habitat variables. The analysis also indicated that the relative frequencies of thermophilic species were most strongly related to spring rainfall.

\section{Discussion}

The drastic modifying effect of grassland management on the organization of Orthoptera assemblages clearly comes from the taxon's sensitivity to vegetation-structure [23], macroclimate [43, 44], microclimate [31], and thermoregulational ability $[45,46]$. Former studies showed that changes in vegetation structure modified quantitative and qualitative parameters of Orthoptera assemblages and extreme disturbances could lead to the local extinction of certain species [35].

Our studies showed that grassland management had the same important effects on the organization of orthopterans 


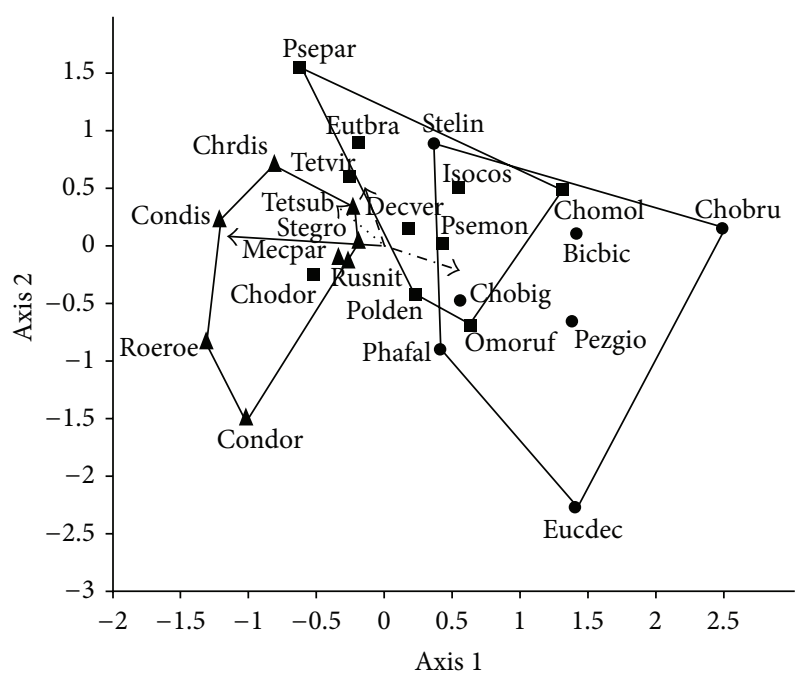

FIgURE 2: Canonical correlation analysis, which included the most significant habitat variables and relative frequency data of orthopteran species occurring in minimum 5 samples, shows that grassland management, rainfall in the period of June to September, rainfall in spring, and annual rainfall affect the organization of orthopteran assemblages. [black circle: thermophilic species (including moderately thermophilic species), black square: mesophilic species, black triangle: hygrophilic species (including moderately hygrophilic species); continuous line: effect of grassland management, dotted line: annual rainfall; broken line: rainfall of the interval from June to September; dots and dashes line: April rainfall; for abbreviations of the species see Table 2].

as macro- and microclimate had. Furthermore, grassland management could intensify the influence of several local and regional parameters.

We found that annual and periodical (from June to September) microclimatic parameters had low importance in the organization of orthopterans but their interactions with grassland management strongly correlated to the structure of these assemblages. The effects of macroclimate could be attributed to its influence on the phenology of species that lay their eggs into the soil. In the studied grasslands, due to their humidity, we found that spring macroclimate was the most important regional factor. It could be explained by the potential water supply from the heavy spring rains, decreasing the number and abundances of hygrophilic and mesophilic species with brief postdiapause egg development $[29,31]$.

Indirect effects of the macroclimate determinate of the grassland microclimate principally. Our results show that the macroclimate of the June-September period has stronger correlations with the microclimate than the grassland management (Table 5). Latter fact is particularly evident in trends of the grassland humidity: this parameter could be at high level caused by sufficient rainfall and underground waterlevel independently from the grassland management. This phenomenon indicates that correlations between management, macroclimate, and orthopteran assemblages should not be based on just climatic requirements of the studied taxon. It was confirmed by linear mixed model in which we found that the effect of grassland management shows significant correlations with much more parameters of the orthopteran assemblages than the microclimate values of the different grass-levels. Strong correlations especially were detected between the abundance of thermophilic species and the grassland microclimate and management.

Summarizing our results, the structure of the studied grasshopper assemblages is mostly correlated to grassland management. Mowing and grazing in the humid grasslands cause higher abundances of thermophilic species than it is characteristic naturally. Although mowing and grazing make the microclimate of the grasslands drier than the direct effects of the macro- and microclimate shape, the above mentioned changes in the structure of the assemblages cannot be explained just with climatic sensitivity of orthopterans. Our results confirmed that abundances of the orthopteran species depend not only on the structure of the vegetation [47] but also on microclimate. There could be several phenomena in the background of the correlations between abundances of the orthopteran species and grass height. Drastic reduction of the grass height by management changes circumstances of the habitats in point of views of feeding [48], mobility [25], predation [49], and energetic connections [27]. Further, the extreme changes in the vegetation structure result in drastic changes in oviposition possibilities. Species that lay their eggs on the vegetation (e.g., Euthystira brachyptera) will decrease if the vertical structure of the grassland becomes more homogenous [50], but grassland management is indirectly also a selecting factor for the orthopterans that lay their eggs into the soil [24], whereas in extended natural habitats the grassland management can modify the contingency of the latter species just in the long term.

Figure 3 shows the periodical (early-summer, latesummer) values of indicator characteristics of the orthopteran assemblages and grassland microclimate in habitats mowed in midsummer and nonmanaged habitats. Caused by phenological phenomena in late summer aspects of the natural humid grasslands the relative frequency of the hygrophilic species increases and the relative frequency of the thermophilic species stagnates. Whereas in mowed habitats, the trend changes: the relative frequency of hygrophilic species decreases, but in case of thermophilic species it drastically increases. Differences between circumstances of mowed and nonmanaged sites are seen not only in the grass height, but also in the microclimate values (Figure 3 ).

Hundred-year data series of the Hungarian Meteorological Service shows effects of global warming in the studied area. Our results may help during the planning of grassland management. Namely, the effects of intensive grassland management can amplify the drying trends of macroclimate. This could change rapidly not only the temperature and humidity of the grassland, but also the structure of the insect assemblages related to vegetation structure. The changes of microclimate could be followed by immigration of thermophilic species from the surrounding habitats and finally by the homogenization of the landscape structure. Our results show that decreasing of species richness and diversity may be avoided if the annual macroclimate is taken into 


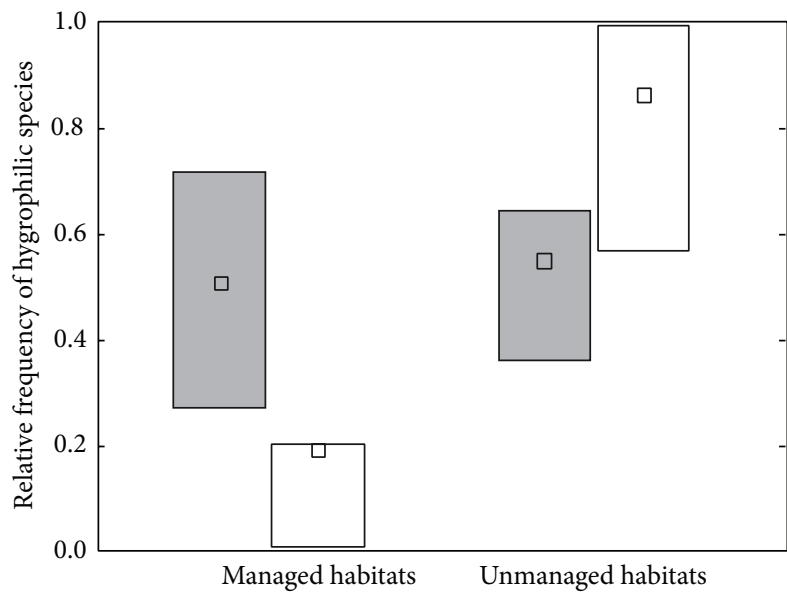

(a)

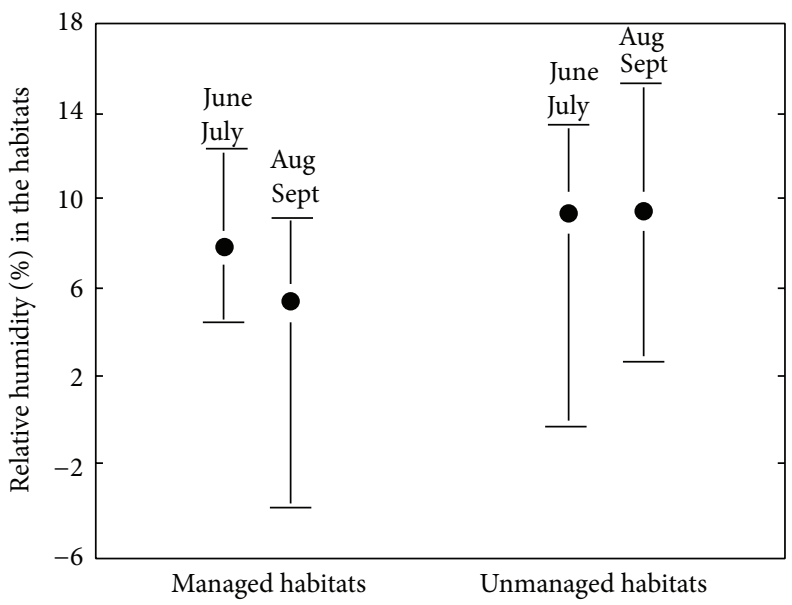

(c)

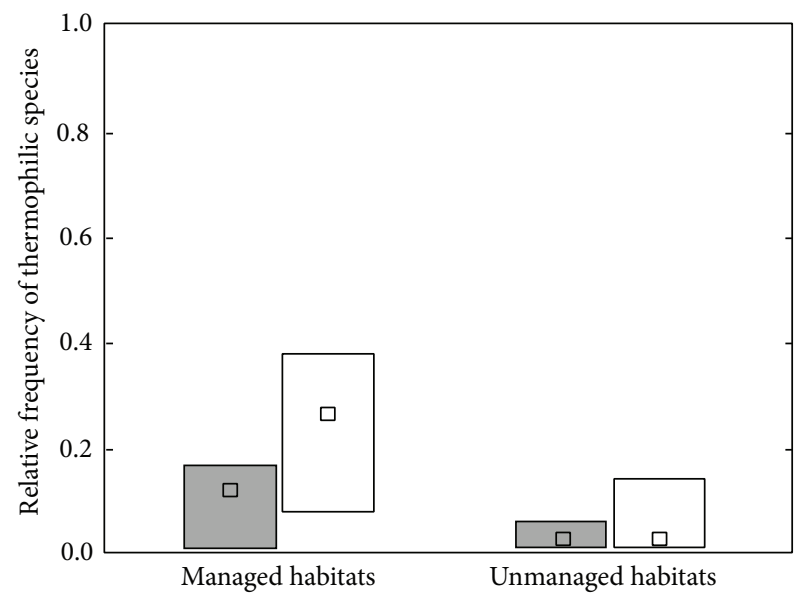

(b)

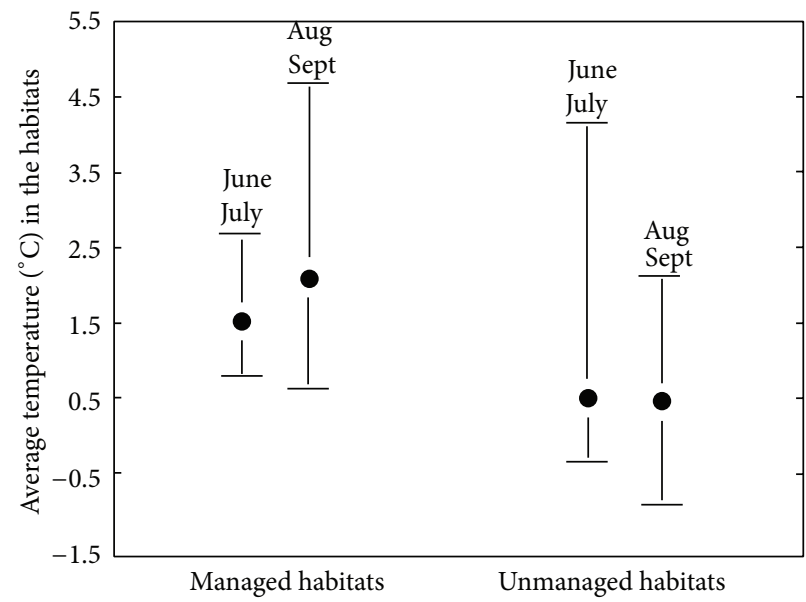

(d)

FIGURE 3: In mowed habitats, the structure of the grasshopper assemblages changes by late summer; relative frequency of the hygrophilic species decreases, relative frequency of the thermophilic species increases drastically [gray bars shaped to 75 th and 25th\% of the hygrophilic and thermophilic species-groups' frequencies in different sites in the period of June-July; white bars indicate the same data in the period of August-September (squares in the boxes show medians)]. Differences between circumstances of mowed and nonmanaged sites are seen not only in the grass height, but also in the values of the grassland humidity and temperature [lower figures draw minimum, maximum, and median of the microclimate data in early (June, July) and late (August, September) summer].

consideration during the planning of grassland management. In extremely dry years mowing should be skipped, if other important aims of natural protection (e.g., repression of invasive species) are not enforcing this.

\section{Conflict of Interests}

The authors declare that there is no conflict of interests regarding the publication of this paper.

\section{Acknowledgments}

The authors' huge thanks go to András Szabadfalvi for the language revision of the text. The study was supported by the HABIT-CHANGE project, implemented through the CENTRAL EUROPE program cofinanced by the European
Regional Development Fund. Researches before 2009 were supported by the Balaton Uplands National Park Directorate.

\section{References}

[1] D. C. Lightfoot, "Climate change and rangeland insects. Beyond boxes and arrows," in Proceedings of the Workshop on Climate Change and Rangeland Management, San Carlos, Ariz, USA, January 2006.

[2] A. Kruess and T. Tscharntke, "Grazing intensity and the diversity of grasshoppers, butterflies, and trap-nesting bees and wasps," Conservation Biology, vol. 16, no. 6, pp. 1570-1580, 2002.

[3] A. Báldi, "Biodiversity in Hungary: advantages and limitations of taxonomically complete faunal inventories," Natural Areas Journal, vol. 19, no. 1, pp. 73-78, 1999. 
[4] R. Menéndez, "How are insects responding to global warming?" Tijdschrift voor Entomologie, vol. 150, pp. 355-365, 2007.

[5] N. Ryrholm, "Global warming and the change of butterfly distributions: a new opportunity for species diversity or a severe threat (Lepidoptera)?" in Proceedings of the 13th International Colloquium of the European Invertebrate Survey, M. Reemer, P. Helsdingen, and R. M. J. C. Kleukers, Eds., pp. 7-12, Leiden, The Netherlands, September 2001.

[6] P. Kočárek, J. Holuša, R. Vlk, P. Marhoul, and T. Zuna-Kratky, "Recent expansions of bush-crickets Phaneroptera falcata and Phaneroptera nana (Orthoptera: Tettigoniidae) in the Czech Republic," Articulata, vol. 23, no. 1, pp. 67-75, 2008.

[7] Z. Kenyeres, Egyenesszárnyú (Orthoptera) fajok és együttesek a Bakonyvidéken [Orthopteran species and assemblages of the Bakony Region] [Ph.D. thesis], Debrecen, Hungary, 2010.

[8] K. A. With and T. O. Crist, "Critical thresholds in species' responses to landscape structure," Ecology, vol. 76, no. 8, pp. 2446-2459, 1995.

[9] P. F. Donald, G. Pisano, M. D. Rayment, and D. J. Pain, “The common agricultural policy, EU enlargement and the conservation of Europe's farmland birds," Agriculture, Ecosystems \& Environment, vol. 89, no. 3, pp. 167-182, 2002.

[10] S. Liu and T. Wang, "Climate change and local adaptation strategies in the middle Inner Mongolia, Northern China," Environmental Earth Sciences, vol. 66, no. 5, pp. 1449-1458, 2012.

[11] J.-P. Maalouf, Y. Le Bagousse-Pinguet, L. Marchand, E. Bâchelier, B. Touzard, and R. Michalet, "Integrating climate change into calcareous grassland management," Journal of Applied Ecology, vol. 49, no. 4, pp. 795-802, 2012.

[12] D. R. Kemp, H. Guodongb, H. Xiangyangc et al., "Innovative grassland management systems for environmental and livelihood benefits," Proceedings of the National Academy of Sciences, vol. 110, no. 21, pp. 8345-8348, 2013.

[13] P. Batáry, K. M. Orci, A. Báldi, D. Kleijn, T. Kisbenedek, and S. Erdos, "Effects of local and landscape scale and cattle grazing intensity on Orthoptera assemblages of the Hungarian Great Plain," Basic and Applied Ecology, vol. 8, no. 3, pp. 280-290, 2007.

[14] K. Kiser, Tagaktive Grossschmetterlinge als Bioindikatoren für landwirtschaftliche Nutzflächen der Zentralschweizer Voralpen, Supplement $\mathrm{zu}$ den Entomologischen Berichten, Luzern, Switzerland, 1987.

[15] L. Bishop and S. E. Riechert, "Spider colonization of agroecosystems mode and source," Environmental Entomology, vol. 19, pp. 1738-1745, 1990.

[16] A. Báldi and T. Kisbenedek, "Orthopteran assemblages as indicators of grassland naturalness in Hungary," Agriculture, Ecosystems and Environment, vol. 66, no. 2, pp. 121-129, 1997.

[17] R. F. Noss, "Indicators for monitoring biodiversity: a hierarchical approach," Conservation Biology, vol. 4, no. 4, pp. 355-364, 1990.

[18] D. L. Pearson, "Selecting indicator taxa for the quantitative assesment of biodiversity," Philosophical Transactions of the Royal Society B, vol. 345, pp. 75-79, 1994.

[19] L. Marini, P. Fontana, M. Scotton, and S. Klimek, "Vascular plant and Orthoptera diversity in relation to grassland management and landscape composition in the European Alps," Journal of Applied Ecology, vol. 45, no. 1, pp. 361-370, 2008.

[20] L. Marini, P. Fontana, A. Battisti, and K. J. Gaston, "Agricultural management, vegetation traits and landscape drive orthopteran and butterfly diversity in a grassland-forest mosaic: a multiscale approach," Insect Conservation and Diversity, vol. 2, no. 3, pp. 213-220, 2009.
[21] L. Marini, P. Fontana, A. Battisti, and K. J. Gaston, "Response of orthopteran diversity to abandonment of semi-natural meadows," Agriculture, Ecosystems \& Environment, vol. 132, no. 3-4, pp. 232-236, 2009.

[22] L. Marini, P. Fontana, S. Klimek, A. Battisti, and K. J. Gaston, "Impact of farm size and topography on plant and insect diversity of managed grasslands in the Alps," Biological Conservation, vol. 142, no. 2, pp. 394-403, 2009.

[23] A. Joern, "Resource utilization and community structure in assemblages of arid grassland grasshoppers (Orthopera: Acrididae)," Transactions of the American Entomological Society, vol. 105, pp. 253-300, 1979.

[24] M. Guido and C. Chemini, "Response of Orthoptera assemblage composition to land-use in the southern Alps of Italy," Mittheilungen der Schweizer. entomologischen Gesellschaft, vol. 73, pp. 353-367, 2000.

[25] Z. Varga, "Trockenrasen im pannonischen Raum: zusammenhang der physiognomischen struktur und der floristischen komposition mit den insektenzönosen," Phytocoenologia, vol. 27, no. 4, pp. 509-571, 1997.

[26] I. V. Stebaev and S. I. Nikita, "Behaviourial patterns of different life forms of grasshoppers from steppes and semideserts of Tuva 3," Zoologicheskii Zhurnal, vol. 55, pp. 715-720, 1976.

[27] R. V. Anderson, C. R. Tracy, and Z. Abramsky, "Habitat selection in two species of short-horned grasshoppers: the role of thermal and hydric stresses," Oecologia, vol. 38, no. 3, pp. 359-374, 1979.

[28] S. J. Willott and M. Hassall, "Life-history responses of British grasshoppers (Orthoptera: Acrididae) to temperature change," Functional Ecology, vol. 12, no. 2, pp. 232-241, 1998.

[29] W. P. Kemp and N. E. Sanchez, "Differences in post diapause thermal requirements for eggs of two rangeland grasshoppers," Canadian Entomologist, vol. 119, pp. 653-661, 1987.

[30] J. C. B. Choudhuri, "Experimental studies on the choice of oviposition sites by two species of Chorthippus (Orthoptera: Acrididae)," Journal of Animal Ecology, vol. 27, pp. 201-215, 1958.

[31] W. K. R. E. Wingerden, A. R. Kreveld, and W. Bongers, "Analysis of species composition and abundance of grasshoppers (Orth., Acrididae) in natural and fertilized grasslands," Journal of Applied Entomology, vol. 113, pp. 138-152, 1992.

[32] G. B. Hewitt, "Review of the factors affecting fecundity, oviposition, and egg survival of grasshoppers in North America," U.S. Department of Agriculture, Agricultural Research Service ARS36, 1985.

[33] D. L. Johnson, R. C. Andrews, M. G. Dolinski, and J. W. Jones, "High numbers but low reproduction of grasshoppers in 1985," The Canadian Agricultural Insect Pest Review, vol. 63, pp. 8-10, 1985.

[34] M. G. Morris, "Differences between the invertebrate faunas of grazed and ungrazed chalk grassland. III. The heteropterous fauna," Journal of Applied Ecology, vol. 6, no. 3, pp. 475-487, 1969.

[35] D. J. Fielding and M. A. Brusven, "Grasshopper (Orthoptera: Acrididae) community composition and ecological disturbance on southern Idaho rangeland," Environmental Entomology, vol. 22, no. 1, pp. 71-81, 1993.

[36] R. J. C. Cannon, “The implications of predicted climate change for insect pests in the UK, with emphasis on non-indigenous species," Global Change Biology, vol. 4, no. 7, pp. 785-796, 1998.

[37] R. Hickling, D. B. Roy, J. K. Hill, R. Fox, and C. D. Thomas, "The distributions of a wide range of taxonomic groups are expanding polewards," Global Change Biology, vol. 12, no. 3, pp. 450-455, 2006. 
[38] A. Krištín, P. Kańuch, and M. Sárossy, "Did the northern range of distribution of two tropical orthopterans (Insecta) change recently?" Polish Journal of Ecology, vol. 55, no. 2, pp. 297-304, 2007.

[39] Z. Dövényi, Cadastre of the Hungarian Microregions, MTA Földrajztudományi Kutatóintézet, Budapest, Hungary, 2nd edition, 2010.

[40] S. Ingrisch and G. Köhler, Die Heuschrecken Mitteleuropas. Die Neue Brehm-Bücherei Bd. 629, Westarp Wissenschaften, Magdeburg, Germany, 1998.

[41] Ø. Hammer, D. A. T. Harper, and P. D. Ryan, "Past: paleontological statistics software package for education and data analysis," Palaeontologia Electronica, vol. 4, no. 1, pp. 1-9, 2001.

[42] StatSoft, STATISTICA for Windows (Computer Program Manual), StatSoft, Tulsa, Okla, USA, 1995.

[43] D. J. Fielding and M. A. Brusven, "Historical analysis of grasshopper (Orthoptera: Acrididae) population responses on climate in Southern Idaho, 1950-1980," Environmental Entomology, vol. 19, no. 6, pp. 1786-1791, 1990.

[44] G. Köhler, J. Perner, and J. Schumacher, "Grasshopper population dynamics and meteorological parameters-Lessons from a case study," Ecography, vol. 22, no. 2, pp. 205-212, 1999.

[45] S. Ingrisch, "Effect of hibernation length on termination of diapause in European Tettigoniidae (Insecta: Orthoptera)," Oecologia, vol. 65, no. 3, pp. 376-381, 1985.

[46] S. J. Willott, "Thermoregulation in four species of British grasshoppers (Orthoptera: Acrididae)," Functional Ecology, vol. 11, no. 6, pp. 705-713, 1997.

[47] K. M. O’Neill, B. E. Olson, M. G. Rolston, R. Wallander, D. P. Larson, and C. E. Seibert, "Effects of livestock grazing on rangeland grasshopper (Orthoptera: Acrididae) abundance," Agriculture, Ecosystems \& Environment, vol. 97, no. 1-3, pp. 5164, 2003.

[48] T. R. Smith and J. L. Capinera, "Host preferences and habitat associations of some Florida grasshoppers (Orthoptera: Acrididae)," Environmental Entomology, vol. 34, no. 1, pp. 210-224, 2005.

[49] G. E. Belovsky and J. B. Slade, "The role of vertebrate and invertebrate predators in a grasshopper community," Oikos, vol. 68, no. 2, pp. 193-201, 1993.

[50] M. Guido and D. Gianelle, "Distribution patterns of four orthoptera species in relation to microhabitat heterogeneity in an ecotonal area," Acta Oecologica, vol. 22, no. 3, pp. 175-185, 2001. 

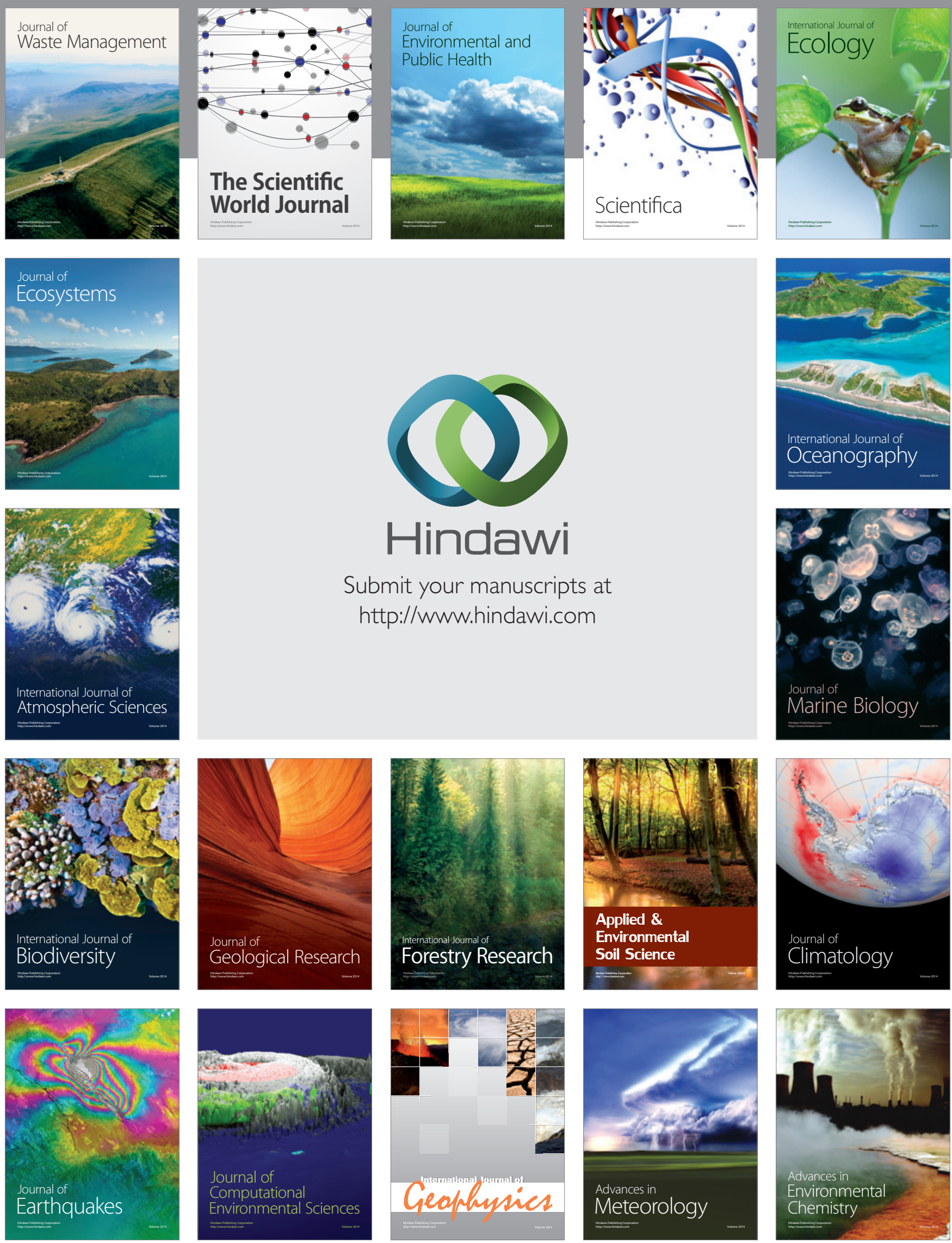